\title{
Genetic Diversity and Population Structure of Fusicladium effusum on Pecan in the United States
}

C. H. Bock and B. W. Wood, USDA-ARS-SEFTNRL, Byron, GA 31008, U.S.A.; K. L. Stevenson, Department of Plant Pathology, Coastal Plain Experiment Station, The University of Georgia, Tifton, GA 31793, U.S.A.; and R. S. Arias, USDA-ARS-NPRL, Dawson, GA 39841, U.S.A.

\begin{abstract}
Bock, C. H., Wood, B. W., Stevenson, K. L., and Arias, R. S. 2014. Genetic diversity and population structure of Fusicladium effusum on pecan in the United States. Plant Dis. 98:916-923.

Fusicladium effusum causes pecan scab, which is the most destructive disease of pecan orchards in the United States. Conidia of the pathogen are spread by rain splash and wind. The fungus is pathogenically diverse; yet there is no information on its genetic diversity or population genetics. Universally primed polymerase chain reaction (UP-PCR) was used to investigate the genetic diversity and population structure on a hierarchical sample of 194 isolates collected from 11 orchard locations from Florida to Texas, consisting of three to four isolates from each of five to six trees at each location. Genetic variation was high throughout the region, with all but nine of the multilocus haplotypes being unique. Nei's average gene diversity ranged from 0.083 for a population from Mississippi to 0.160 for a population from Kansas. An analysis of molecular variance of the hierarchically sampled populations found

that the majority of the genetic variability $(82.6 \%)$ occurred at the scale of the individual tree and only relatively small amounts among populations in trees from an orchard $(5.0 \%)$ or within groups (i.e., orchard location populations) (12.5\%). The results suggest little population differentiation in F. effusum in the southeastern United States, although $\varphi p t$ values of genetic distance for pairwise comparisons indicated some populations could be differentiated from others. There was evidence of linkage disequilibrium in certain populations, and the common occurrence of asexual reproduction in $F$. effusum could lead to measurable linkage disequilibrium under certain circumstances. However, the degree of genetic diversity and the scale over which diversity is distributed is evidence that $F$. effusum undergoes regular recombination despite no known sexual stage.
\end{abstract}

Pecan scab, caused by the fungal pathogen Fusicladium effusum (G. Winter), is typically the most destructive disease of pecan (Carya illinoinensis (Wangenh.) K. Koch). The disease causes considerable economic loss to growers in the southeastern United States and other relatively wet, humid pecan-growing regions in the world. It can substantially reduce both quality and yield of nuts $(22,25,56)$. The pathogen is known only by its asexual phase, with the conidia dispersed by wind and splash (24). When conditions are conducive for dispersal and infection, there can be severe disease throughout the canopy of pecan trees (5).

Pecan scab management is primarily by a combination of fungicide application and host resistance (22). The fungus is resistant to several classes of fungicides $(53,55,57)$, and although novel fungicides continue to become available (4), they too could succumb; thus, durable host resistance to $F$. effusum is an attractive option. But the fungus is pathogenically diverse $(12,13,16,27)$, with genetic adaptation by the pathogen resulting in previously scab-resistant cultivars developing disease (22). Some data suggest that there is physiological specialization with separate pathogenic 'races' on different pecan genotypes $(12,13)$. Breeding to develop and release new cultivars continues, but there is a risk that the pathogen will adapt to the novel resistance developed, which is especially problematic for controlling disease in a tall, long-lived crop like pecan.

Plant pathogens have several ways to maintain and generate genetic diversity (10). Understanding the pathogen population diver-

Corresponding author: C. H. Bock, E-mail: clive.bock@ars.usda.gov

* The $\boldsymbol{e}$-Xtra logo stands for "electronic extra" and indicates that Figure 4 appears in color in the online edition.

Accepted for publication 17 January 2014.

http://dx.doi.org/10.1094/PDIS-12-13-1229-RE

This article is in the public domain and not copyrightable. It may be freely reprinted with customary crediting of the source. The American Phytopathological Society, 2014. sity and genetics is fundamental to developing an informed strategy for host resistance breeding that maximizes the probability of generating durable, scab-resistant germplasm. Those plant pathogens possessing a mixed reproductive cycle (asexual and at least one sexual cycle each epidemic cycle) have a high potential for gene flow and thus pose the greatest risk to host resistance genes. Appropriate incorporation of resistance genes into the host and resistance gene deployment in the field are needed to maximize durability (36), and these decisions should be based on the evolutionary potential of the pathogen. Pecan scab is known only by its asexual, conidial phase (24), but lack of an identified sexual stage is by no means evidence of absence. Numerous related fungal plant pathogens, initially known only by an asexual stage, are now known to have a sexual stage that provides a basis for explaining the genetic diversity characteristic of a freely recombining organism $(29,40,52,60)$, and if a sexual stage has not been identified, the mating type loci have been characterized and found to be in near or complete equilibrium, providing compelling evidence for the existence of an as yet unknown sexual stage $(28,32,33)$.

Apart from a comparison of two dominant marker methods (6), there is no information available on the population genetics of $F$. effusum (although limited molecular genetic data has been used to aid classification of this fungus; 3,54). Population genetics and genetic diversity have been studied for several related species. Preliminary studies of genetic diversity in the apple scab pathogen (Venturia inaequalis) using dominant markers (random amplified polymorphic DNA [RAPD]) and internal transcribed spacer (ITS) region sequences demonstrated a high degree of genetic diversity $(58,59)$. More recent studies using codominant markers have allowed a more in-depth analysis of populations worldwide (21), providing new insights into the epidemiology and possible management of the disease (64). Overall, the coevolution of $V$. inaequalis and Malus species (domestic and natural) is characterized by a high level of genetic diversity and relatively low population differentiation; interpreted as showing the importance of human transport and the existence of sexual spores that are dispersed 
moderate distances (21). A population with this mating and dispersal behavior ensures genetic recombination, gene flow, and genetic equilibrium. Similar genetic studies have been done with several other species including Pyrenophora teres (50), Leptosphaeria maculans $(17)$, and Septoria tritici $(37,68)$. Studies of the genetic diversity of $F$. effusum are needed to provide a framework for understanding its genetic diversity and as a basis for informed deployment of scab resistance genes in Carya germplasm (36).

Bock et al. (6) recently compared RAPDs and universally primed polymerase chain reaction (UP-PCR) as dominant marker systems to investigate the molecular genetic diversity of F. effusum. Both systems have the advantages of being inexpensive and relatively straightforward, but the UP-PCR system was found to be more reliable. Dominant markers can provide very useful information on the genetic diversity and population structure of an organism. Although codominant marker methods (such as restriction fragment length polymorphism [RFLP] and simple sequence repeats [SSRs]) are more sophisticated, sensitive, and informative (38), they are also more expensive and time-consuming to develop.

The objective of this study was to use a hierarchical sampling approach (38) and UP-PCR markers to provide insight into the structure and genetic diversity of $F$. effusum in the southeastern United States.

\section{Materials and Methods}

Sample locations and isolation of $\boldsymbol{F}$. effusum. A total of 194 isolates of $F$. effusum was obtained from scab-diseased leaves or fruit of pecan from 11 populations across the southeastern United States (Table 1 and Fig. 1). Eighteen diseased leaves or fruit were collected from five to six trees (three to four leaves per tree) in each of the orchards, ensuring that the leaf samples were taken individually from around the canopy of a particular tree, and ensuring that trees were separated by at least four rows or trees on a grid basis, where orchard size allowed. Thus, the sampling was hierarchical, comprising the regional scale (between orchards, 106 to $1,321 \mathrm{~km}$ ), between trees within an orchard (40 to $400 \mathrm{~m})$, and between leaves on an individual tree (5 to $20 \mathrm{~m}$ ). The isolates were sampled from both commercially available cultivars in orchards and naturally seeded native-tree groves. The process of isolation for $F$. effusum has been previously described (6). Briefly, conidia of F. effusum were scraped from single lesions on the sampled leaf using a scalpel, and a dilute spore solution was prepared in sterile distilled water. Multiple 0.1- $\mu$ l aliquots were spread on the surface of replicate water agar plates (WA, amended with lactic acid [0.50 $\mathrm{ml} /$ liter], streptomycin [0.20 g/liter], tetracycline [0.05 g/liter], and chloramphenicol $[0.05 \mathrm{~g} /$ liter] $)$, which were incubated at $27^{\circ} \mathrm{C}$ for $24 \mathrm{~h}$ under fluorescent lights on a 12/12 h day/night cycle. A single germinated spore of $F$. effusum was excised on an agar plug using a scalpel under a microscope, and was transferred to antibioticamended potato dextrose agar (PDA, amended as for WA) and incubated for 3 to 5 weeks at $25^{\circ} \mathrm{C}$, at which time the DNA was extracted from the sample.
DNA extraction, PCR, and electrophoresis. The fungal mycelium was scraped from the surface of the agar with a scalpel $(\sim 200$ $\mathrm{mg}$ ) and the DNA extracted using a ZymoResearch DNA extraction kit (ZymoResearch, Irvine, CA), following a slightly modified protocol for DNA extraction from fungi (54) using a Tissuelyser (Qiagen, Valencia, CA, USA) to lyse the fungal mycelium. Once obtained, the DNA was quantified using a Nanodrop spectrophotometer (Nanodrop Products, Wilmington, DE) and stored in TE buffer at $-20^{\circ} \mathrm{C}$. The UP-PCR primers (obtained from Eurofins MWG Operon, Huntsville, AL) had been previously tested and found to be reliable and repeatable (6). UP-PCR primers produce dominant markers (9), and have been previously used on pathogens related to $F$. effusum (44). The working primer concentration was $20 \mu \mathrm{M}$ for the UP-PCR. A total reaction volume of $50 \mu \mathrm{l}$ was used:

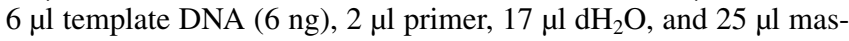
ter mix (Promega, Madison, WI). The UP-PCR reaction conditions were as follows (modified from Obanor et al. [44]): denaturation at $94^{\circ} \mathrm{C}$ for $2 \mathrm{~min}, 94^{\circ} \mathrm{C}$ for $50 \mathrm{~s}$, annealing at $56^{\circ} \mathrm{C}$ for $90 \mathrm{~s}$, and primer extension at $72^{\circ} \mathrm{C}$ for $1 \mathrm{~min}$ all repeated 34 times, with a final extension step of $72^{\circ} \mathrm{C}$ for $10 \mathrm{~min}$. The PCR products were separated using agarose-gel electrophoresis, stained with gel red (Biotium, Inc., Hayward, CA), and visualized under ultraviolet light. Images were photographed and scored manually by the same individual (to ensure consistency) for the presence (1) or absence (0) of the marker/amplicon. Fragment sizes were estimated based on their migration relative to a known standard (50 to 10,000 bp Ladder; Bionexus, Inc., Oakland, CA). Any amplicon that was sufficiently pronounced to be readily visible was scored as present (6).

Data analysis. The number of markers observed for the 194 isolates with each primer was counted, and the percent polymorphic calculated by population, and by marker. The number of clones (isolates sharing identical multi-locus haplotypes) was calculated. The marker data for all 194 isolates were analyzed using an Un-

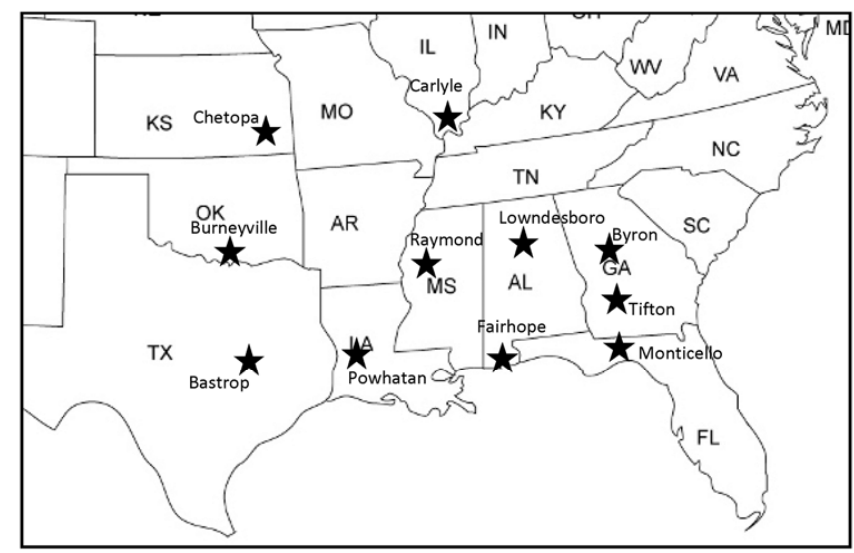

Fig. 1. A map of the southeastern United States showing sample sites for populations of Fusicladium effusum collected for the population genetic analysis.

Table 1. Location, elevation, source cultivar, and numbers of isolates of Fusicladium effusum collected to assess population genetic diversity in the southeastern United States

\begin{tabular}{lclcl}
\hline Source location (population) & Number of isolates & Latitude and longitude of site & Elevation $(\mathbf{m})$ & Pecan cultivar \\
\hline Fairhope, Alabama & 18 & $30^{\circ} 32.681^{\prime} \mathrm{N} / 87^{\circ} 52.918^{\prime} \mathrm{W}$ & 62 & Desirable \\
Lowndesboro, Alabama & 18 & $32^{\circ} 21.236^{\prime} \mathrm{N} / 86^{\circ} 38.393^{\prime} \mathrm{W}$ & 43 & Kiowa \\
Byron, Georgia & 18 & $32^{\circ} 65.522^{\prime} \mathrm{N} / 83^{\circ} 65.522^{\prime} \mathrm{W}$ & 156 & Desirable \\
Chetopa, Kansas & 14 & $37^{\circ} 01.360^{\prime} \mathrm{N} / 95^{\circ} 02.783^{\prime} \mathrm{W}$ & 266 & Native seedling \\
Powhatan, Louisiana & 18 & $31^{\circ} 50.211^{\prime} \mathrm{N} / 93^{\circ} 13.328^{\prime} \mathrm{W}$ & 33 & Desirable \\
Raymond, Mississippi & 18 & $32^{\circ} 11.297^{\prime} \mathrm{N} / 90^{\circ} 29.537^{\prime} \mathrm{W}$ & 70 & Desirable \\
Monticello, Florida & 18 & $30^{\circ} 32.265^{\prime} \mathrm{N} / 83^{\circ} 55.060^{\prime} \mathrm{W}$ & 69 & Desirable \\
Burneyville, Oklahoma & 18 & $33^{\circ} 52.823^{\prime} \mathrm{N} / 97^{\circ} 15.164^{\prime} \mathrm{W}$ & 123 & Western Schley \\
Bastrop, Texas & 18 & $30^{\circ} 03.554^{\prime} \mathrm{N} / 97^{\circ} 18.402^{\prime} \mathrm{W}$ & Wichita \\
Tifton, Georgia & 18 & $31^{\circ} 30.388^{\prime} \mathrm{N} / 83^{\circ} 38.287^{\prime} \mathrm{W}$ & 112 & Desirable \\
Carlyle, Illinois & 18 & $38^{\circ} 29.323^{\prime} \mathrm{N} / 89^{\circ} 30.212^{\prime} \mathrm{W}$ & 143 & Native seedling \\
\hline
\end{tabular}


weighted Paired Group Method of Arithmetic Averages (UPGMA) cluster analysis (SAS V9.3, proc cluster, method=average; SAS Institute, Cary, NC) and a bootstrap analysis (100 samples) performed to generate a consensus phenogram based on the Jacard coefficient using WinBoot (65). For all calculations, the data were analyzed as dominant markers, with the genetics assumed to be based on a haploid organism, as is typical with asexual forms of other fungi (e.g., 7,51,61).

Two methods were used to explore population genetic diversity: Shannon's information index (31) and Nei's unbiased measure of gene diversity (41) were calculated using GenAIEx V6.5 (46). Pairwise population comparisons were made using Nei's genetic distance, and the parameter $\varphi p t$ (which is analogous to Wright's F-statistics, Fst [63] when the data are haploid or binary [45] and is a measure of population differentiation) was used to determine significance in the differentiation between any two populations (using 999 permutations). If the observed $\varphi p t$ value differed significantly from zero, the null hypothesis of no genetic differentiation between populations was rejected.

Linkage disequilibrium was explored using the Index of Association $\left(I_{A}\right)(8,35)$. This tests the importance of clonal versus sexual reproduction within each population and was calculated using Multilocus V1.3 $(1,2)$. The $I_{A}$ was calculated for each population and compared to the expected value (zero) assuming no linkage disequilibrium, but it is sensitive to the number of loci $(1,2)$. Thus, a second linkage disequilibrium measure, $r_{d}$, was calculated which is independent of the number of loci. Significance of $r_{d}$ was likewise tested by its deviation from the expected value (zero). There were 1,000 randomizations performed for each population.

The hierarchical sampling structure allowed an analysis of molecular variance (AMOVA) to be performed (Arlequin V3.5; 19) assuming haplotypic data with several groups of populations. The
AMOVA partitions the total variance into covariance components at the within population scale (trees), among populations within groups (among trees within orchards), and among groups (orchards) to quantify the diversity accounted for at each spatial scale. The analysis was based on 10,000 permutations, and the percentage of the total variation calculated at each level in the hierarchy (within tree, within orchard, within population, and among populations). To compare populations, a UPGMA analysis of population structure based on Nei's genetic distance (42) was calculated using Popgene V1.31 (66). In addition, digenic linkage disequilibrium was tested among pairs of loci using Arlequin V3.5. To reach a random starting point, 3,000 dememorization steps were performed, and 100,000 alternative permutations were run.

Evidence for population genetic structuring was further explored using Structure V2.3.4 (20,49). The 194 individuals were obtained from 11 orchard locations, and thus results for population structuring $(K)$ from $K=1$ to $K=11$ were tested. Each estimate of $K$ was based on 20 iterations, each iteration comprising a burn-in of 50,000 and a subsequent Markov Chain Monte Carlo chain of 100,000. An admixture model was used. The relationship between the probability $(\operatorname{Pr}(X / K))$ of the data for a particular $K$ was calculated (along with the standard deviation of the 20 estimates), and was graphed against $K$ (1 to 11$)$. Due to peaks in $\operatorname{Pr}(X / K)$ often failing to reliably detect the true $K$, Evanno et al. (18) developed an ad hoc quantity $(\Delta K)$ based on the second order rate of change of $\operatorname{Pr}(X / K)$ that shows a clear peak at true $K$. The estimated membership coefficient of each individual in each cluster $(Q)$ was calculated, and represented graphically by showing each isolate as a vertical line partitioned into $K$ colored segments that represent that individual's estimated membership fraction in each of the inferred clusters at $K=11$.

Table 2. The universally primed polymerase chain reaction primers used in the study, number of markers, and percent polymorphic markers among 194 isolates of Fusicladium effusum collected from 11 populations in the southeastern United States

\begin{tabular}{|c|c|c|c|}
\hline Name $^{a}$ & Nucleotide sequence $\left(5^{\prime}-3^{\prime}\right)$ & Reference & $\begin{array}{l}\text { Markers per primer } \\
\text { (\% polymorphic) }\end{array}$ \\
\hline AA2M2 & CTGCGACCCAGAGCGG & 34 & $6(66.6)$ \\
\hline AS4 & TGTGGGCGCTCGACAC & 34 & $13(100.0)$ \\
\hline AS15inv & CATTGCTGGCGAATCGG & 15 & $10(100.0)$ \\
\hline L15 & GAGGGTGGCGGTTCT & 15 & $19(100.0)$ \\
\hline L15/AS19 & GAGGGTGGCGGCTAG & 34 & $16(93.8)$ \\
\hline Total & & & $64(92.1)$ \\
\hline
\end{tabular}

${ }^{a}$ Primers were previously used to study genetic diversity in a related species, Fusicladium (Spilocea) oleagina (44).

Table 3. Number of haplotypes, percent polymorphic loci, Shannon's information index, Nei's unbiased measure of gene diversity, and measures of linkage disequilibrium among population of Fusicladium effusum from the southeastern United States ${ }^{\mathrm{a}}$

\begin{tabular}{|c|c|c|c|c|c|c|c|}
\hline \multirow[b]{2}{*}{ Population } & \multirow{2}{*}{$\begin{array}{c}\text { Haplotypes } \\
\text { (genotypic } \\
\text { diversity, \%) }\end{array}$} & \multirow{2}{*}{$\begin{array}{c}\text { Percent } \\
\text { polymorphic } \\
\text { loci }(\%)\end{array}$} & \multirow{2}{*}{$\begin{array}{c}\text { Shannon's } \\
\text { information } \\
\text { index (SE) }\end{array}$} & \multirow{2}{*}{$\begin{array}{l}\text { Nei's unbiased } \\
\text { measure of gene } \\
\text { diversity (SE) }\end{array}$} & \multirow{2}{*}{$\begin{array}{c}\text { Significant pairwise linkage } \\
\text { disequilibrium }(P=0.05), \\
\text { percent loci }(\%)^{\mathbf{b}}\end{array}$} & \multicolumn{2}{|c|}{$\begin{array}{c}\text { Indices }\left(I_{A}, r_{d}\right) \text { of multilocus } \\
\text { association }^{\mathrm{c}}\end{array}$} \\
\hline & & & & & & $I_{A}$ & $r_{d}$ \\
\hline $\mathrm{AL}(\mathrm{F})$ & $18(100.0)$ & 34.4 & $0.146(0.028)$ & $0.092(0.019)$ & $21 / 210(10.0)$ & $0.119(0.2)$ & $0.006(0.2)$ \\
\hline $\mathrm{AL}(\mathrm{L})$ & $17(94.4)$ & 45.3 & $0.187(0.029)$ & $0.117(0.020)$ & $55 / 406(13.5)$ & $0.524(0.01)$ & $0.019(0.01)$ \\
\hline GA(B) & $18(100.0)$ & 42.2 & $0.176(0.030)$ & $0.111(0.020)$ & $55 / 351(15.7)$ & $1.341(<0.001)$ & $0.053(<0.001)$ \\
\hline KS & $14(100.0)$ & 62.5 & $0.259(0.029)$ & $0.160(0.020)$ & 153/780 (19.6) & $4.985(<0.001)$ & $0.131(<0.001)$ \\
\hline LA & $18(100.0)$ & 29.7 & $0.141(0.030)$ & $0.091(0.020)$ & 19/171 (11.1) & $0.156(0.2)$ & $0.009(0.2)$ \\
\hline MS & $18(100.0)$ & 42.2 & $0.140(0.025)$ & $0.083(0.016)$ & 17/351 (4.8) & $1.978(<0.001)$ & $0.079(<0.001)$ \\
\hline FL & $18(100.0)$ & 36.0 & $0.154(0.029)$ & $0.097(0.019)$ & $17 / 253(6.7)$ & $1.420(<0.001)$ & $0.066(<0.001)$ \\
\hline OK & $18(100.0)$ & 39.1 & $0.150(0.027)$ & $0.093(0.018)$ & $26 / 300(8.7)$ & $0.423(0.04)$ & $0.018(0.04)$ \\
\hline $\mathrm{TX}$ & $18(100.0)$ & 40.6 & $0.167(0.028)$ & $0.103(0.019)$ & 30/325 (9.2) & $0.262(0.1)$ & $0.011(0.1)$ \\
\hline $\mathrm{GA}(\mathrm{T})$ & $18(100.0)$ & 51.6 & $0.208(0.031)$ & $0.131(0.021)$ & $36 / 528(6.8)$ & $0.624(<0.001)$ & $0.020(0.002)$ \\
\hline IL & $18(100.0)$ & 50.0 & $0.204(0.030)$ & $0.128(0.020)$ & 70/496 (14.1) & $0.624(0.001)$ & $0.020(0.004)$ \\
\hline All pops & $185(94.3)$ & $43.0(2.75)$ & $0.176(0.009)$ & $0.110(0.006)$ & $436 / 1711(25.5)$ & $1.250(<0.001)$ & $0.026(<0.001)$ \\
\hline
\end{tabular}

a Population abbreviations: Fairhope, Alabama (AL(F)), Lowndesboro, Alabama (AL(L)), Byron, Georgia (GA(B)), Chetopa, Kansas (KA), Powhatan, Louisiana (LA), Raymond, Mississippi (MS), Monticello, Florida (FL), Burneyville, Oklahoma (OK), Bastrop, Texas (TX), Tifton, Georgia (GA(T)), Carlyle, Illinois (IL).

${ }^{\mathrm{b}}$ Based on Fischer's exact test extended to a contingency table of arbitrary size (Arlequin V3.5, 19). To reach a random starting point 3,000 dememorization steps were performed, and 100,000 alternative permutations were subsequently explored.

${ }^{\mathrm{c}}$ The indices of multilocus association $\left(I_{A}, r_{d}\right)$ were calculated by measuring the distance between all pairs of loci, and comparing the actual value to the expected value (zero) assuming there was no linkage disequilibrium (Multilocus V2.1,2). Number of randomizations to estimate $I_{A}$ and $r_{d}$ was 1,000 . 
A Mantel test was used to compare the relationship between Log genetic distance (Nei's genetic distance) and Log physical distance between population locations $(\mathrm{km})$.

\section{Results}

There were a total of 64 scorable UP-PCR markers, and the majority scored $(92.1 \%)$ were polymorphic among the 194 isolates (Table 2), confirming that they had utility in detecting genetic variability in this pathogen. Within each population, the vast majority of isolates had a unique haplotype (Table 3), and between 29.7 (LA) and $62.5 \%(\mathrm{KS})$ of the loci were polymorphic within each population, with a total of $43 \%$ polymorphic over all populations. The number of isolates (194) precluded presenting the consensus dendrogram, but the bootstrapped node values of the first two branches were $87 \%$ ( 2 and 192 isolates in separate clades) and $52 \%$ ( 1 and 191 isolates in separate clades), respectively. The third branch had a node value of only 29\% (14 and 177 isolates in separate clades), and bootstrap values at branching below that level were 1 to $99 \%$, depending on the node. Isolates did not form into clades related to source location.

Both Nei's unbiased measure of gene diversity and Shannon's information index (Table 3) suggested essentially similar and mod-

Table 4. Inter-population and intra-population shared haplotypes ${ }^{\mathrm{a}}$ of Fusicladium effusum in the southeastern United States

\begin{tabular}{lc}
\hline Population with shared haplotype & Shared haplotypes \\
\hline Alabama (Lowndesboro) & 1 \\
Alabama (Lowndesboro) $\times$ Florida (Monticello) & 1 \\
Louisiana (Powhatan) $\times$ Oklahoma (Burneyville) & 1 \\
$\quad \times$ Illinois (Carlyle) & 1 \\
Mississippi (Raymond) $\times$ Oklahoma (Burneyville) & 2 \\
Florida (Monticello) $\times$ Oklahoma (Burneyville) & 1 \\
Oklahoma (Burneyville) $\times$ Texas (Bastrop) & 1 \\
Texas (Bastrop) $\times$ Louisiana (Powhatan) & 1 \\
Texas (Bastrop) $\times$ Illinois (Carlyle) & 9 \\
Total shared haplotypes & \\
\hline
\end{tabular}

${ }^{a}$ Shared haplotypes occur either within or between two or more populations. erate to high gene diversity in all 11 populations of $F$. effusum sampled throughout the region (Table 3) (Nei's measure of gene diversity $=0.083[\mathrm{MS}]$ to $0.160[\mathrm{KS}]$, Shannon's information index = $0.140[\mathrm{MS}]$ to $0.259[\mathrm{KS}])$. Both measures were highly correlated $(r=0.99, P<0.0001)$. The proportion of loci with significant pairwise linkage disequilibrium within each population was most often relatively low and ranged from $6.8 \%(\mathrm{GA}(\mathrm{T}))$ to $19.6 \%(\mathrm{KS})$. The composite sample (all populations taken as a single unit) had $25.5 \%$ of loci with significant pairwise linkage disequilibrium. The observed indices of multilocus association $\left(I_{A}\right.$ and $\left.r_{d}\right)$ were significantly different from zero for 8 (AL(L), GA(B), KS, MS, FL, OK, $\mathrm{GA}(\mathrm{T})$, and IL) of the 11 populations, suggesting that in these populations a hypothesis of solely random mating was questionable, but in three of the populations there was evidence for random mating. Overall, the number of shared or clonal haplotypes was very low (Table 4$)$, with only a single population $(\mathrm{AL}(\mathrm{L}))$ having two isolates with a common haplotype, and eight other haplotypes being shared between two to three populations; thus the majority of isolates were unique multilocus haplotypes, with an average regionwide genotype diversity of 0.94 (or $94 \%$ of the maximum possible). The number of markers was similar among populations (Fig. 2), and although a very few private markers were evident in some populations, these were very rare, although some populations had certain markers that were locally common (KS, GA(T), and IL).

The pairwise comparisons of populations (Table 5) based on Nei's genetic distance showed for the most part the distance between populations was relatively small (Nei's genetic distance $=$ 0.0113 to 0.0473 ), although the $\varphi p t$ values indicated there were significant differences between many pairs of populations. The UPGMA analysis of the populations based on Nei's genetic distance showed the relative divergence, with certain populations (for example, KS) being more divergent than others (Fig. 3). The AMOVA showed the majority of the genetic variability $(82.6 \%)$ occurred at the scale of the individual tree (Table 6), with only a relatively small amount being explained among populations in trees in an orchard $(5.0 \%)$ or within groups (i.e., orchard populations) $(12.5 \%)$, which suggests that there is very little population differentiation in F. effusum in the southeastern United States based on data from UP-PCR markers.

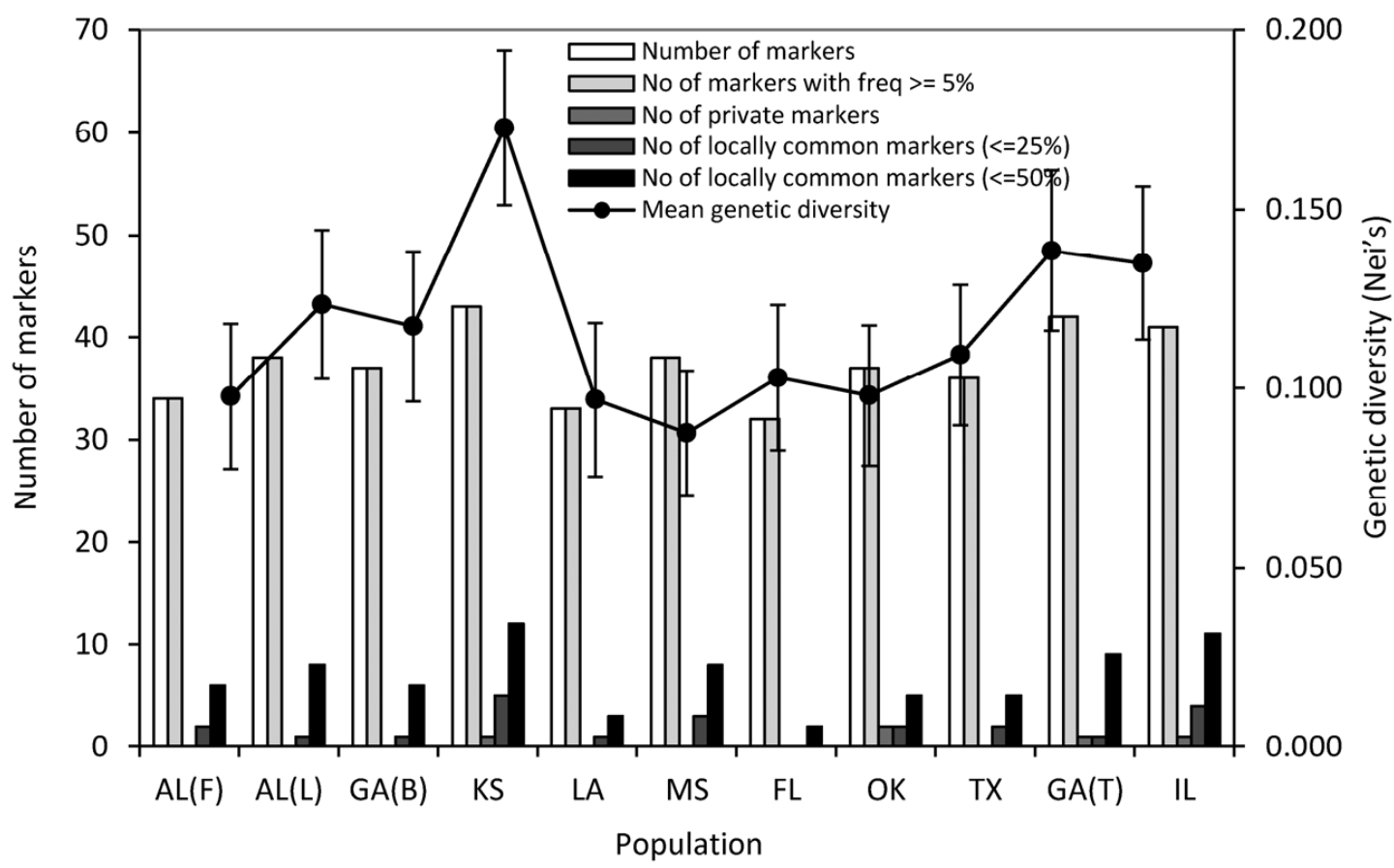

Fig. 2. Total number of markers, numbers of markers with frequency $>5 \%$, number of private markers, and numbers of locally common markers with frequency $\leq 25$ and $\leq 50 \%$ in each population, respectively. Nei's unbiased measure of genetic diversity is also plotted for each population. Population abbreviations: Fairhope, Alabama (AL(F)), Lowndesboro, Alabama (AL(L)), Byron, Georgia (GA(B)), Chetopa, Kansas (KA), Powhatan, Louisiana (LA), Raymond, Mississippi (MS), Monticello, Florida (FL), Burneyville, Oklahoma (OK), Bastrop, Texas (TX), Tifton, Georgia (GA(T)), Carlyle, Illinois (IL). 
Structure analysis supported this contention. The plot of $\operatorname{Pr}(X / K)$ against $K=1$ to 11 failed to show a clear mode for true $K$ (lower graph, Fig. 4A). However, the plot of $\Delta K$ against $K=1$ to 11 (upper chart, Fig. 4A) showed a peak at $K=1$, which suggested that there was no meaningful sub-structuring in these data, and the isolates could be considered a single population. The $Q$ plot (Fig. 4B) was based on $K=11$ rather than $K=1$. By presenting $K=11$, the relatively uniform admixture of haplotypes in each population is demonstrated, providing compelling evidence for little population differentiation in F. effusum. The alpha plots (not shown) were stabilized within the burn-in period for the simulation. Thus, these data provide support for the AMOVA analysis that the majority of the genetic admixture resides within populations.

The Mantel test to explore any association between physical distance and genetic distance showed no evidence of a relationship ( $r$ $=0.0694, P=0.6$ ).

\section{Discussion}

These data suggest that $F$. effusum is a genetically diverse organism, confirming an earlier report demonstrating it was polymorphic (6). The dominant UP-PCR markers successfully differentiated the vast majority of isolates showing their utility in quantifying genetic diversity for $F$. effusum. Out of a total of 194 isolates, only 9 were clonal (4.6\%).

The gene diversity observed in this study (Nei's measure of gene diversity $=0.083$ to 0.160 ) using UP-PCR is comparable with that observed among other related fungal pathogens (for example, Pyrenophora, Gremeniella, Venturia, Mycospaerella [Stagonospora], and Rhynchosporium spp.) using either isozymes (23) or other dominant marker systems $(47,61)$, including from a study based on RAPDs with the closely related $V$. inaequalis $(58,59)$. The ability of marker systems to give different estimates of gene diversity has been commented on before, and codominant marker systems such as RFLPs and SSRs may be more sensitive and provide more realistic and greater measures of gene diversity (38). Nonetheless, our results confirm that considerable genetic variability exists within populations of $F$. effusum.

Among the multilocus haplotypes, the associations among the different alleles at different loci can provide evidence for clonality. The linkage disequilibrium detected by UP-PCR within the 11 populations in this study was low, ranging from $6.8 \%(\mathrm{GA}(\mathrm{T}))$ to $19.6 \%$ (KS), which is comparable to levels of linkage disequilibrium found in populations of related fungal species that experience regular sexual recombination $(11,32,47,50)$. The index of association $\left(I_{A}\right.$ and the equivalent statistic $\left.r_{d}\right)$ was devised to help distinguish the null hypothesis of recombination from clonality (35), and in three of the 11 populations there was no evidence of clonality (observed $I_{A}$ not significantly different from zero), but in the remaining eight populations, the observed value of $I_{A}$ was significantly different from zero; which is not unexpected as F. effusum is known to reproduce very effectively through its asexual phase, allowing departure from panmixis. Previous studies have found a proportion of populations of known sexually reproducing fungi that have an $I_{A}$ significantly different from zero using both dominant and codominant marker systems $(11,17,32,50)$. It is worth noting that factors other than clonal reproduction, including decay of historic disequilibrium, population admixture, and genetic drift, might result in $I_{A}$ values different from zero (39).

There was some genetic differentiation between certain pairs of populations of $F$. effusum, but not others, and the UPGMA analysis of all 194 isolates failed to identify the source populations, suggesting that they were genetically relatively homogeneous and could be considered a fairly uniform metapopulation. The analysis of molecular variance showed that the majority of genetic diversity $(82.6 \%)$ was present at the scale of the individual tree. The remainder was explained among orchards and among trees within orchards. Thus, the majority of diversity occurred at the smallest spatial scale sampled. Analysis from Structure also suggested that

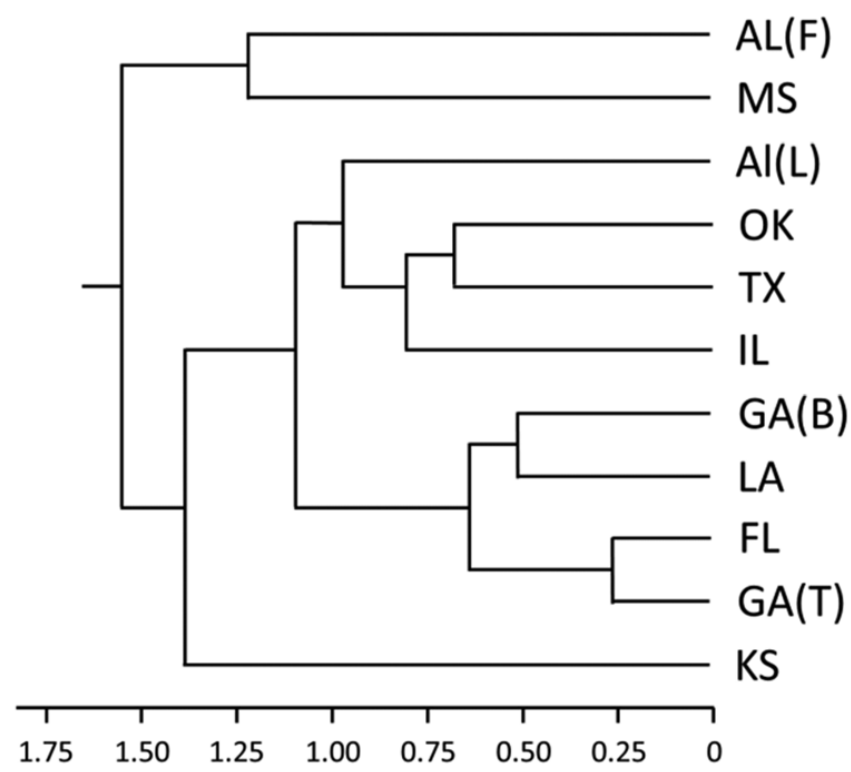

Fig. 3. Unweighted paired group method of arithmetic averages (UPGMA) separation of populations of Fusicaldium effusum based on universally primed polymerase chain reaction (UP-PCR) using the multiple populations option (Popgene V1.31, 67) and based on Nei's measure of genetic distance (42). Population abbreviations: Fairhope, Alabama (AL(F)), Lowndesboro, Alabama (AL(L)), Byron, Georgia (GA(B)), Chetopa, Kansas (KA), Powhatan, Louisiana (LA), Raymond, Mississippi (MS), Monticello, Florida (FL), Burneyville, Oklahoma (OK), Bastrop, Texas (TX), Tifton, Georgia (GA(T)), Carlyle, Illinois (IL). Scale shows Euclidean distance.

Table 5. Nei's unbiased measures of genetic distance ${ }^{\mathrm{a}}$ (42) (below diagonal) and $\varphi p t$ values $^{\mathrm{b}}$ (above the diagonal) $^{\mathrm{c}}$

\begin{tabular}{|c|c|c|c|c|c|c|c|c|c|c|c|}
\hline Population & $\mathbf{A L}(\mathbf{F})$ & $\mathbf{A L}(\mathbf{L})$ & $\mathbf{G A}(\mathbf{B})$ & KS & LA & MS & FL & OK & TX & GA(T) & IL \\
\hline $\mathrm{AL}(\mathrm{F})$ & & $0.125^{*}$ & $0.193^{*}$ & $0.221 *$ & $0.234^{*}$ & $0.169^{*}$ & $0.219^{*}$ & $0.191 *$ & $0.140^{*}$ & $0.152^{*}$ & $0.150^{*}$ \\
\hline $\mathrm{AL}(\mathrm{L})$ & 0.0213 & & $0.098 *$ & $0.122 *$ & $0.187^{*}$ & $0.145^{*}$ & $0.159 *$ & $0.128 *$ & $0.093 *$ & $0.123^{*}$ & $\underline{0.078}$ \\
\hline GA(B) & 0.0327 & 0.0189 & & $0.097 *$ & $\underline{0.062}$ & $0.224 *$ & $\underline{0.050}$ & $0.124 *$ & $0.112 *$ & $\underline{0.061}$ & $\underline{0.085}$ \\
\hline $\mathrm{KS}$ & 0.0473 & 0.0288 & 0.0227 & & $\overline{0.164} *$ & $0.234 *$ & $\overline{0.112} *$ & $0.140 *$ & $0.159^{*}$ & $\overline{0.108} *$ & $\overline{0.068}$ \\
\hline LA & 0.0365 & 0.0324 & 0.0113 & 0.0335 & & $0.232 *$ & $\underline{0.076}$ & $0.126^{*}$ & $0.153^{*}$ & $0.070 *$ & $0.120^{*}$ \\
\hline MS & 0.0239 & 0.0233 & 0.0366 & 0.0480 & 0.0340 & & $\overline{0.271} *$ & $0.164 *$ & $0.131 *$ & $0.144^{*}$ & $0.144^{*}$ \\
\hline FL & 0.0350 & 0.0279 & 0.0100 & 0.0236 & 0.0124 & 0.0429 & & $0.134 *$ & $0.137^{*}$ & $\underline{0.006}$ & $0.101^{*}$ \\
\hline OK & 0.0290 & 0.0219 & 0.0206 & 0.0285 & 0.0187 & 0.0232 & 0.0206 & & $0.083 *$ & $\overline{0.101}$ * & $0.074 *$ \\
\hline TX & 0.0223 & 0.0173 & 0.0198 & 0.0349 & 0.0242 & 0.0197 & 0.0224 & 0.0138 & & $\underline{0.074}$ & $0.085^{*}$ \\
\hline GA(T) & 0.0279 & 0.0257 & 0.0137 & 0.0278 & 0.0136 & 0.0249 & 0.0045 & 0.0188 & 0.0152 & & 0.065 \\
\hline IL & 0.0271 & 0.0168 & 0.0175 & 0.0187 & 0.0215 & 0.0246 & 0.0190 & 0.0141 & 0.0168 & 0.0156 & \\
\hline
\end{tabular}

${ }^{a}$ For Nei's measure of genetic distance, bold indicates all pairwise comparisons $<0.0180$.

${ }^{\mathrm{b}}$ For $\varphi p t$, italics and asterisks indicates $\varphi p t(P \leq 0.001)$ showing significant genetic differentiation between pairs of populations, and underscores represent nonsignificant comparisons (based on 999 permutations).

${ }^{\mathrm{c}}$ Population abbreviations: Fairhope, Alabama (AL(F)), Lowndesboro, Alabama (AL(L)), Byron, Georgia (GA(B)), Chetopa, Kansas (KA), Powhatan, Louisiana (LA), Raymond, Mississippi (MS), Monticello, Florida (FL), Burneyville, Oklahoma (OK), Bastrop, Texas (TX), Tifton, Georgia (GA(T)), Carlyle, Illinois (IL). 
genetic diversity was for the most part uniformly distributed throughout the region, with a single cluster describing the distribution of the genetic admixture. Several other studies on related fungal pathogens (Venturia, Mycospaerella [Stagonospora], Alternaria, Leptosphaeria, and Rhynchosporium spp.) have similarly found that a greater proportion of the genetic diversity can be found at a small spatial scale, including on a single plant or in a plot compared to larger spatial scales $(26,30,32,38,64)$. These pathogens either have, or are believed to have, a sexual stage that provides the basis for regular recombination, and combined with dispersal through the sexual and/or asexual stage this allows gene flow over distance $(32,50)$. It should be noted that the asexual stages may play an important role in the epidemic in some cases (64), resulting in locally genetically similar populations. No sexual stage has been identified for $F$. effusum, so there is no known basis for it to undergo sexual recombination. However, lack of an identi- fied sexual stage is not evidence for its non-existence, and compelling evidence for sexual stages can be found through studying the frequency of mating type genes $(28,32,33,50)$. If the mating type loci are in equilibrium, there is likely to be an undiscovered sexual stage $(28,33)$. In the absence of a sexual stage of $F$. effusum, it would be valuable to locate and study the mating type loci. In the present study, there was no detectable effect of physical distance on genetic relatedness between isolates. Effect of distance has been previously reported with related pathogens (38), although it was often measured over considerably larger geographic distances. Also, a slight effect of physical distance was observed for $F$. effusum in a much smaller study (6). Thus, it is possible that UPPCR markers were insufficiently sensitive to discern a distance effect, or perhaps the area over which the sample was taken is too small to readily discern distance effects with a pathogen metapopulation so genetically homogeneous.

Table 6. Analysis of molecular variance ${ }^{\text {a }}$ of 11 populations of Fusicladium effusum in the southeastern United States

\begin{tabular}{|c|c|c|c|c|}
\hline Source of variation & df & Sum of squares & Variance components & Percentage of variation \\
\hline Among groups (orchards) & 10 & 134.5 & 0.53 & 12.5 \\
\hline Among populations within groups (among trees within orchards) & 54 & 222.7 & 0.21 & 5.0 \\
\hline Within populations (trees) & 129 & 451.2 & 3.50 & 82.6 \\
\hline Total & 193 & 808.36 & 4.24 & \\
\hline
\end{tabular}

a Analysis of molecular variance for the populations of $F$. effusum was based on 10,000 permutations using Arlequin V3.5 (19). Data were analyzed as haplotypic data, with several groups of populations.

A

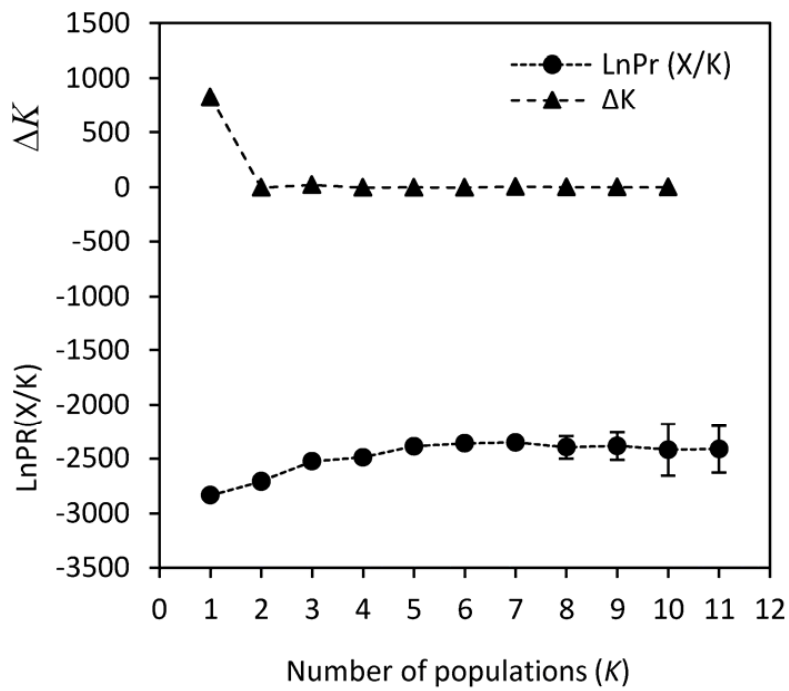

B

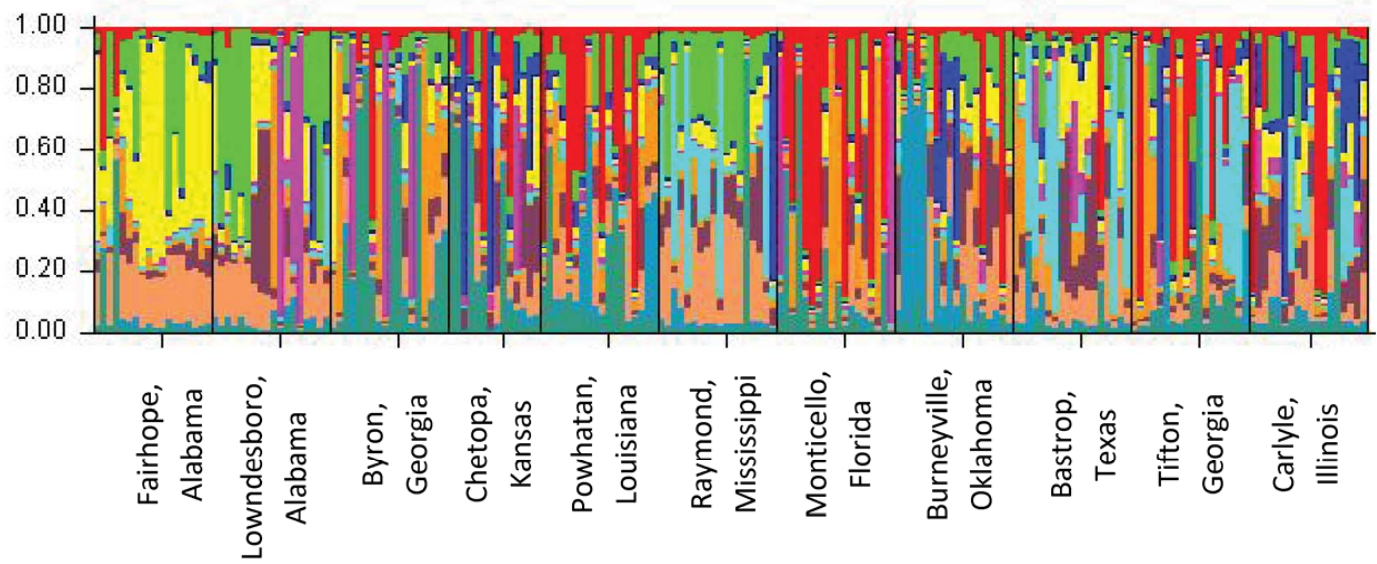

Fig. 4. Results of the Structure analysis of the universally primed polymerase chain reaction (UP-PCR) marker data for $K=1$ to 11 populations of Fusicladium effusum sampled throughout the southeastern United States. Average log likelihood $\operatorname{Ln} \operatorname{Pr}(X / K)( \pm S D)$ and $\Delta K$ indicating true $K$ (number of population groups based on genetic partitioning) (A), and $Q$ plot of $K=11$ demonstrating the high degree of admixture among populations precluding population differentiation (B). 
Other explanations might be made for the distribution of genetic diversity. At least one study found a similar hierarchy of genetic diversity, but attribution of causation was postulated to be due to recent multiple introductions as responsible in the absence of a sexual stage (44). In that case, it was a related pathogen ( $F$. oleagi$n e a)$, infecting olive; the pathogen is an exotic to New Zealand, and no sexual stage is reported for the fungus in New Zealand or elsewhere (53). In contrast, F. effusum is native to the southeastern United States and was first described on Carya tomentosa $(=C$. $a l b a$ ) in 1885 (62), making it unlikely that multiple introductions of founder populations would result in this pattern of diversity. There are other possible explanations, including parasexuality through the Pontecorvo cycle (48), but this has been confirmed for very few fungal pathogens as a vehicle driving the pattern of genetic diversity $(14,43,67)$. Sexual stages of fungal pathogens can be cryptic and restricted by exacting environmental requirements both temporally and spatially, and if a sexual stage should exist for $F$. effusum, this will most likely be the case.

In conclusion, $F$. effusum appears to be a genetically variable pathogen, and that diversity appears to be well distributed throughout the pecan-growing region of the southeastern United States. This suggests that the methods of recombination and/or dispersal of propagules allow a genetically reasonably uniform metapopulation to be maintained. With most genetic diversity at the scale of individual trees, pecan breeders will need to consider strategies that ensure durable resistance (36). However, if a sexual stage exists, it too may become a target of management strategies to reduce its efficiency in maintaining diversity over the whole region, which will contribute to durability of host resistance $(12,13)$, and in addition, minimize the risk of the development and spread of fungicide resistance, which is also an issue in F. effusum (55). Considering the destructive nature of this disease on pecan, and the need for a fuller understanding of the pathogen diversity, population structure, and gene flow, codominant markers should be developed to further explore the population genetic characteristics observed in the current study using UP-PCR.

\section{Acknowledgments}

We appreciate the input of Dr. Mike Hotchkiss and technical help of Minling Zhang, Wanda Evans, Ginger Moreland, and Teddy Endalew. We appreciate the funding support of the USDA-ARS through CRIS project 6606-21220-011-00D. This article reports the results of research only. Mention of a trademark or proprietary product is solely for the purpose of providing specific information and does not constitute a guarantee or warranty of the product by the U.S. Department of Agriculture and does not imply its approval to the exclusion of other products that may also be suitable.

\section{Literature Cited}

1. Agapow, P. M., and Burt, A. 2001. Indices of multilocus linkage disequilibrium. Bioessays 1:101-102.

2. Agapow, P. M., and Burt, A. 2003 Multilocus. Version 2.3. University of London, London; http://www.agapow.net/software/multilocus/

3. Beck, A., Ritschel, A., Schubert, K., Braun, U., and Triebel, D. 2005. Phylogenetic relationships of the anamorphic genus Fusicladium s. lat. as inferred by ITS nrDNA data. Mycol. Prog. 4:111-116.

4. Bock, C. H., Brenneman, T. B., Hotchkiss, M. W., and Wood, B. W. 2012. Evaluation of phosphites to control scab (Fusicladium effusum) on susceptible pecan (Carya illinoinensis) in the southeastern USA. Crop Prot. 36:5864.

5. Bock, C. H., Cottrell, T. E., Hotchkiss, M. W., and Wood, B. W. 2013. Vertical distribution of scab in large pecan trees. Plant Dis. 97:626-634.

6. Bock, C. H., Endalew, T. T., Biswas, B. K., Yadav, A. K., Hotchkiss, M. W., Stevenson, K. L., and Wood, B. W. A comparison of UP-PCR and RAPD markers to study genetic diversity of Fusicladium effusum (G. Winter), cause of pecan scab. For. Pathol. doi: 10.1111/efp.12090 (http://online library.wiley.com/doi/10.1111/efp.12090/abstract).

7. Bock, C. H., Thrall, P. H., and Burdon, J. J. 2005. Genetic structure of populations of Alternaria brassicicola suggests the occurrence of sexual recombination. Mycol. Res. 109:227-236.

8. Brown, A. H. D., Feldman, M. W., and Nevo, E. 1980. Multilocus structure in natural populations of Hordeum spontaneum. Genetics 96:523-536.

9. Bulat, S. A., Lübeck, M., Mironenko, N., Jensen, D. F., and Lübeck, P. S. 1998. UP-PCR analysis and ITS1 ribotyping of strains of Trichoderma and Gliocladium. Mycol. Res. 102:933-943.

10. Burdon, J. J., and Silk, J. 1997. Sources and patterns of diversity in plantpathogenic fungi. Phytopathology 87:664-669.
11. Chaijuckham, P., Baek, J.-M., Greer, C. A., Webster, R. K., and Davis, R. M. 2010. Population structure of Rhizoctonia aryzae-sativae in California rice fields. Phytopathology 100:502-510.

12. Conner, P. J., and Stevenson, K. L. 2004. Pathogenic variation of Cladosporium caryigenum isolates and corresponding differential resistance in pecan. HortScience 39:553-557.

13. Converse, R. H. 1960. Physiologic specialization in Fusicladium effusum and its evaluation in vitro. Phytopathology 50:527-531.

14. Crawford, M. S., Chumley, F. G., Weaver, C. G., and Valent, B. 1986. Characterization of the heterokaryotic and vegetative diploid phases of $\mathrm{Mag}$ naporthe grisea. Genetics 114:1111-1129.

15. Cumagun, C. J. R., Hockenhull, J., and Lübeck, M. 2000. Characterization of Trichoderma isolates from Philippine rice fields by UP-PCR and rDNAITS1 analysis: Identification of UP-PCR markers. J. Phytopathol. 148:109115 .

16. Demaree, J. B., and Cole, J. R. 1929. Behavior of Cladosporium effusum (Wint.) Demaree on some varieties of pecan. J. Agric. Res. 38:363-370.

17. Dilmaghani, A., Gladieux, P., Gout, L., Giraud, T., Brunner, C., Stachowiak, A., Balesdent, M.-H., and Rouxel, T. 2012. Migration patterns and changes in population biology associated with the worldwide spread of the oilseed rape pathogen Leptosphaeria maculans. Mol. Ecol. 21:2519-2533.

18. Evanno, G., Regnaut, S., and Goudet, J. 2005. Detecting the number of clusters of individuals using the software STRUCTURE: A simulation study. Mol. Ecol. 14:2611-2620.

19. Excoffier, L., Laval, G., and Schneider, S. 2005. Arlequin ver. 3.0: An integrated software package for population genetics data analysis. Evol. Bioinform. Online 1:47-50

20. Falush, D., Stephens, M., and Pritchard, J. K. 2007. Inference of population structure using multilocus genotype data: Dominant markers and null alleles. Mol. Ecol. N. 7:574-578.

21. Gladieux, P., Zhang, X.-G., Róldan-Ruiz, I., Caffier, V., Leroy, T., Devaux, M., van Glabeke, S., Coart, E., and Le Cam, B. 2010. Evolution of the population structure of Venturia inaequalis, the apple scab fungus, associated with the domestication of its host. Mol. Ecol. 19:658-674.

22. Goff, W. D., McVay, J. R., and Gazaway, W. S. 1996. Pecan production in the southeast. Alabama Coop. Ext. Syst. Circ. ANR-459, University, Auburn, AL. P222.

23. Goodwin, S. B., Saghai Maroof, M. A., Allard, R. W., and Webster, R. K. 1993. Isozyme variation within and among populations of Rhychosporium secalis in Europe, Australia and the United States. Mycol. Res. 97:49-58.

24. Gottwald, T. R., and Bertrand, P. F. 1982. Patterns of diurnal and seasonal airborne spore concentrations of Fusicladium effusum and its impact on a pecan scab epidemic. Phytopathology 72:330-335.

25. Gottwald, T. R., and Bertrand, P. F. 1988. Effects of an abbreviated pecan disease control program on pecan scab disease increase and crop yield. Plant Dis. 72:27-32.

26. Gout, L., Eckert, M., Rouxel, T., and Balesdent, M. H. 2006. Genetic variability and distribution of mating type alleles in field populations of Leptosphaeria maculans from France. Appl. Environ. Microbiol. 72:185-191.

27. Graves, C. H. 1975. Breeding for pecan scab resistance. Proc. SouthEastern Pecan Growers Assoc. 61:168-171.

28. Groenewald, M., Groenewald, J. Z., Harrington, T. C., Abeln, E. C. A., and Crous, P. W. 2006. Mating type gene analysis in apparently asexual Cercospora species is suggestive of cryptic sex. Fung. Genet. Biol. 43:813-825.

29. Horn, B. W., Moore, G. G., and Carbone, C. 2009. Sexual reproduction in Aspergillus flavus. Mycologia 101:423-429.

30. Keller, S. M., McDermott, J. M., Pettway, R. E., Wolfe, M. S., and McDonald, B. A. 1997. Gene flow and sexual reproduction in the wheat glume blotch pathogen Phaeosphaeria nodorum (anamorph Stagonospora nodorum). Phytopathology 87:353-358.

31. Lewontin, R. C. 1972. The apportionment of human diversity. Evol. Biol 6:381-398.

32. Linde, C. C., Liles, J. A., and Thrall, P. H. 2010. Expansion of genetic diversity in randomly mating founder populations of Alternaria brassicicola infecting Cakile maritima in Australia. Appl. Environ. Microbiol. 76:19461954.

33. Linde, C. C., Zala, M., Ceccarelli, S., and McDonald, B. A. 2003. Further evidence for sexual reproduction in Rhynchosporium secalis based on distribution and frequency of mating-type alleles. Fung. Genet. Biol. 40:115-125.

34. Lübeck, P. S., Alekhina, I. A., Lübeck, M., and Bulat, S. A. 1998. UP-PCR genotyping and rDNA analysis of Ascochyta pisi Lib. J. Phytopathol. 146:51-55.

35. Maynard Smith, J., Smith, N. H., O'Rourke, M., and Spratt, B. G. 1993. How clonal are bacteria? P.N.A.S., USA 90:4384-4388.

36. McDonald, B. A., and Linde, C. 2002. Pathogen population genetics, evolutionary potential, and durable resistance. Annu. Rev. Phytopathol. 40:349379.

37. McDonald, B. A., Pettway, R. E., Chen, R. S., Boeger, J. M., and Martinez, J. P. 1995. The population genetics of Septoria tritici (teleomorph Mycosphaerella graminicola). Can. J. Bot. 73:292-301.

38. McDonald, B. A., Zhan, J., and Burdon, J. J. 1999. Genetic structure of Rhynchosporium secalis in Australia. Phytopathology 89:639-645.

39. Milgroom, M. G. 1996. Recombination and the multilocus structure of fungal populations. Annu. Rev. Phytopathol. 14:457-477. 
40. Müller, E. 1952. Pilzliche Erreger der Getreideblattdürre. Phytopathol. Zeitsch. 19:403-416

41. Nei, M. 1973. Analysis of gene diversity in subdivided populations. P.N.A.S., USA 70:3321-3323

42. Nei, M. 1978. Estimation of average heterozygosity and genetic distance from a small number of individuals. Genetics 89:583-590.

43. Newman, P. L., and Owen, H. 1985. Evidence of asexual recombination in Rhynchosporium secalis. Plant Pathol. 34:338-340.

44. Obanor, F. O., Walter, M., Jones, E. E., Candy, J., and Jaspers, M. V. 2010. Genetic variation in Spilocaea oleagina populations from New Zealand olive groves. Aust. Plant Pathol. 39:508-516.

45. Peakall, R., and Smouse, P. E. 2006. GENALEX 6: Genetic analysis in Excel. Population genetic software for teaching and research. Mol. Ecol. N. 6:288-295

46. Peakall, R., and Smouse, P. E. 2012. GenAlEx 6.5: Genetic analysis in Excel. Population genetic software for teaching and research - an update. Bioinformatics 28:2537-2539.

47. Peever, T. L., and Milgroom, M. G. 1994. Genetic structure of Pyrenophora teres populations determined with RAPD markers. Can. J. Bot. 72:915-923.

48. Pontecorvo, G. 1956. The parasexual cycle in fungi. Annu. Rev. Microbiol. 10:393-400.

49. Pritchard, J. K., Stephens, M., and Donnelly, P. 2000. Inference of population structure using multilocus genotype data. Genetics 155:945-959.

50. Rau, D., Brown, A. H. D., Brubaker, C. L., Attene, G., Balmas, V., Saba, E., and Papa, R. 2003. Population genetic structure of Pyrenophora teres Drechs., the causal agent of net blotch of barley (Hordeum vulgare L.). Theor. Appl. Genet. 106:947-959.

51. Salamati, S., Zhan, J., Burdon, J. J., and McDonald, B. A. 2000. The genetic structure of field populations of Rhynchosporium secalis from three continents suggests moderate gene flow and regular recombination. Phytopathology 90:901-908.

52. Sanderson, F. R. 1972. A Mycosphaerella species as the ascogenous state of Septoria tritici Rob. \& Desm. N.Z. J. Agric. Res. 21:277-281.

53. Schubert, K., Ritschel, A., and Braun, U. 2003: A monograph of Fusicladium s. lat. (Hyphomycetes). Schlechtendalia 9:1-132.

54. Seyran, M., Brenneman, T. B., and Stevenson, K. L. 2010. A rapid method to monitor fungicide sensitivity in the pecan scab pathogen, Fusicladium effusum. Crop Prot. 29:1257-1263.

55. Seyran, M., Nischwitz, C., Lewis, K. J., Gitaitis, R. D., Brenneman, T. B., and Stevenson, K. L. 2010. Phylogeny of the pecan scab fungus Fusicladium effusum $\mathrm{G}$. Winter based on the cytochrome $\mathrm{b}$ gene sequence. Mycol.
Prog. 9:305-308.

56. Stevenson, K. L. 1999. Fungicide resistance management in pecans. Pages 1-6 in: The Pecan Industry: Current Situation and Future Challenges. B. E. McCraw, E. H. Dean, and B. W. Wood, eds. 3rd Nat. Pecan Workshop Proc. USDA Agricultural Research Service, 1998-04.

57. Stevenson, K. L., and Bertrand, P. F. 2001. Within-season dynamics of yield loss due to pecan scab fruit infections. (Abstr.) Phytopathology 91:S85.

58. Stevenson, K. L., Bertrand, P. F., and Brenneman, T. B. 2004. Evidence for reduced sensitivity to propiconazole in the pecan scab fungus in Georgia. (Abstr.) Phytopathology 94:S99.

59. Tenzer, I., and Gessler, C. 1997. Subdivision and genetic structure of four populations of Venturia inaequalis in Switzerland. Eur. J. Plant Pathol. 103:565-571.

60. Tenzer, I., and Gessler, C. 1999. Genetic diversity of Venturia inaequalis across Europe. Eur. J. Plant Pathol. 105:545-552.

61. Wallwork, H., and Spooner, B. 1988. Tapesia yallundae, the teleomorph of Pseudocercosporella herpotrichoides. Trans. Br. Mycol. Soc. 91:703-705.

62. Wang, X. R. 1997. Genetic variability in the canker pathogen fungus, Grem meniella abietina. Contribution of sexual compared with asexual reproduction. Mycol. Res. 101:1195-1201.

63. Winter, G. 1885. New North America fungi. J. Mycol. 1:101-102.

64. Wright, S. 1978. Evolution and the Genetics of Populations. Vol. IV. Variability Within and Among Natural Populations. University of Chicago Press, Chicago.

65. Xu, X., Harvey, N., Roberts, A., and Barbara, D. 2013. Population variation of apple scab (Venturia inaequalis) within mixed orchards in the UK. Eur. J. Plant Pathol. 135:97-104.

66. Yap, I. V., and Nelson, R. J. 1996. Winboot: A program for performing bootstrap analysis of binary data to determine the confidence limits of UPGMA-based dendrograms. Manila: IRRI, 1996.

67. Yeh, F. C., and Boyle, T. 1999. Popgene: Microsoft window-based freeware for population genetic analysis. Version 1.31, http://www.ualberta.ca/ $\sim$ fyeh/popgene_download.html University of Alberta, Alberta, Canada.

68. Zeigler, R. S., Cuoc, L. X., Scott, R. P., Bernardo, M. A., Chen, D. H.,Valent. B., and Nelson, R. J. 1995. The relationship between lineage and virulence in Pyricularia grisea in the Philippines. Phytopathology $85: 443-451$.

69. Zhan, J., Pettway, R. E., and McDonald, B. A. 2003. The global genetic structure of the wheat pathogen Mycosphaerella graminicola is characterized by high nuclear diversity, low mitochondrial diversity, regular recombination, and gene flow. Fungal Genet. Biol. 38:286-297. 